\title{
Population responses of plant-associated invertebrates to foraging by largemouth bass fry (Micropterus salmoides)
}

\author{
G. Winfield Fairchild ${ }^{1}$ \\ Div. Biological Sciences, University of Michigan, Ann Arbor, MI 48109, U.S.A. \\ 1 Present Address: Biology Dept., Central Michigan University, Mt. Pleasant, MI 48859, U.S.A.
}

Keywords: Micropterus, Sida, chironomids, chydorids, fry, littoral

\begin{abstract}
The effect of foraging by largemouth bass fry (Micropterus salmoides) upon invertebrates associated with aquatic macrophytes was determined using six $4 \mathrm{~m}^{2}$ exclosures in Cochran Lake, Michigan during June 1978. The cladoceran Sida crystallina rapidly declined in exclosures with fry, but increased in control exclosures without fry. Chironomids and chydorids showed little change in the exclosures.

Invertebrate populations and foraging by fry were also monitored in the lake during 1976 and 1979 . Sida declined rapidly in June of both years. In 1979 , a decline from $2.2 \times 10^{3}$ to $0.3 \times 10^{3}$ individuals per $\mathrm{m}^{2}$ and a sharp drop in the proportion of adults between 19 and 22 June coincided with the entry of a large school of fry into the study site on 19 June. Chironomids also declined during June of both years, while chydorids became increasingly abundant in mid-summer and showed no evidence of depletion by the fish.

These results suggest that populations of certain prey, which are found locally in high densities in the littoral zone, may be highly susceptible to brief episodes of intense predation by fish fry.
\end{abstract}

\section{Introduction}

Whereas fish predation has been known for some time to modify littoral invertebrate communities (e.g., Hayne \& Ball 1956; Gerking 1962; Hall et al. 1970), studies specifically examining the effects of foraging by young-of-the-year fish (fry) upon littoral species have been few. Phoenix (1976) has shown that plant-associated invertebrates may be rapidly depleted by fish fry. Such depletion of a principal food source may considerably modify the growth of young fish (Aggus \& Elliott 1975; Rainwater \& Hauser 1975).

This paper presents density estimates for three littoral invertebrate taxa associated with the water lily Nymphaea odorata in Cochran Lake, Michigan: Sida crystallina, chironomid larvae, and chydorid Cladocera. Sida is a filter feeding cladoceran which attaches to macrophytes by means of a sticky gland on the back of its carapace. The chironomids consisted largely of case-building periphyton and detritus feeders, although free-living herbivores and carnivores were also seen in small numbers. The chydorids, consisting of about 8 common species, are also primarily grazers on the surfaces of macrophytes. Whereas Sida varied from approximately 800 to $2500 \mu \mathrm{m}$ in total length, the chydorids were much smaller, ranging from 400 to $900 \mu \mathrm{m}$. Sida was largely restricted to plant surfaces, but portions of both the chironomid and chydorid communities were found on the lake bottom beneath the plants. Other groups, including cyclopoid copepods, gastropods, and immature insects, were less frequently observed. The taxonomy and microdistribution of the invertebrates associated with macrophytes in Cochran Lake are described elsewhere (Fairchild 1980, 1981).

The effects of feeding by largemouth bass fry (Micropterus salmoides) on Sida, the chironomids and chydorids are first evaluated using experimen-

Hydrobiologia 96, 169-176 (1982). 0018-8158/82/0962-0169/\$01.60.

(c) Dr W. Junk Publishers, The Hague. Printed in The Netherlands. 
tal exclosures in situ. These results are then used to interpret changes in densities of the three taxa, and in the size distribution of Sida, associated with the presence of largemouth bass fry in Cochran Lake during 1976 and 1979.

\section{Materials and methods}

Cochran Lake is a mesotrophic, moderately hardwater lake of 11.0 ha and $3.5 \mathrm{~m}$ maximum depth in northern lower Michigan. The lake has no inlet; a small outlet at the SW end often dries up by mid-summer. Aquatic vegetation dominates much of the perimeter of the lake and becomes abundant in deeper areas by August. The lake supports large numbers of bluegill sunfish (Lepomis macrochirus) and largemouth bass. Much smaller populations of darters (Etheostoma) and several cyprinid species also occur in the lake, and yellow perch (Perca flavescens) and pumpkinseed sunfish (L. gibbosus) are occasionally captured by fishermen.

In both the exclosure experiment and the population studies of 1976 and 1979, samples of littoral invertebrates were taken in stands of Nymphaea using a 'box sampler' (Fairchild 1980, 1981). The sampling device consisted of a rectangular plastic basin with a $1.3 \mathrm{~m}$ wooden pole attached to one side. Pull cords strung along the pole served to draw an aluminum sheet across the aperture of the basin, enclosing one or more leaves of Nymphaea and 101 of surrounding water. A funnel with windows of $70 \mu \mathrm{m}$ mesh screening was affixed to the side of the basin opposite the aperture. When the device was closed, inverted, and then lifted from the water, invertebrates on the Nymphaea leaves or swimming in the $10 \mathrm{l}$ of water were concentrated in the funnel to a volume of approximately $50 \mathrm{ml}$. They were then transferred to $100 \mathrm{ml}$ jars by opening a pinch clamp at the end of the funnel, narcotized by adding carbonated water and preserved in $4 \%$ formalin buffered with sodium tetraborate.

The abundances of Sida, the chironomids and chydorids all vary directly with leaf surface available (Fairchild 1980, 1981). Their densities per $\mathrm{m}^{2}$ of lake surface in stands of Nymphaea in Cochran Lake were estimated on each sampling date as follows. Leaf surface area was first computed for each sample, and an average leaf surface area was calculated from the leaves collected on each sampling date. Leaf densities were assessed by different methods, described below. Total leaf surface area per $\mathrm{m}^{2}$ was then estimated by multiplying average leaf surface area by leaf density. Densities of plant-associated species, first expressed per unit plant surface in the samples, were then multiplied by the total leaf surface area per $\mathrm{m}^{2}$ on that date to obtain numbers of organisms per $\mathrm{m}^{2}$ lake surface.

\section{Exclosures}

Six $2 \times 2 \mathrm{~m}$ exclosures were placed in Cochran Lake on 6 and 7 June 1978. Each exclosure was constructed of fiberglass window screening (mesh size approximately $1.3 \mathrm{~mm}$ ) stapled to wooden frames, then placed in a stand of Nymphaea at the south end of the lake (Fig. 1). The four corner posts and bottom of the screening were sunk into the soft mud substrate; the tops of the exclosures extended $10 \mathrm{~cm}$ above the water and were left open.

Although the mesh size of the screening was not small enough to completely prevent migration of zooplankton through the walls, fouling reduced aperture sizes prior to the start of the experiment, and effects of migration were assumed to be small rela-

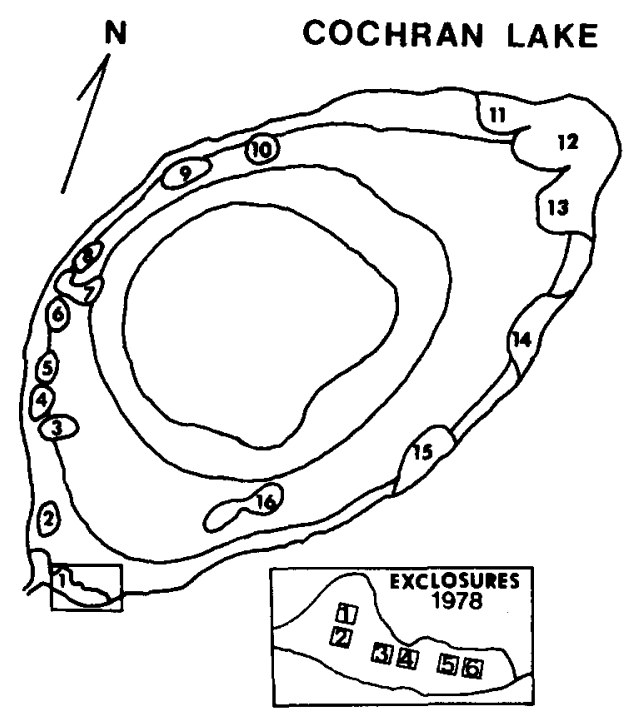

Fig. 1. Map of Cochran Lake, indicating locations of vegetation sites visited daily to check for fry during June and July 1979. Isopleths are $0.7 \mathrm{~m}, 1.5 \mathrm{~m}$ and $3.0 \mathrm{~m}$. The south end of the lake is expanded to show locations of the 6 exclosures used in 1978. The transect in 1979 extended at right angles from the shoreline through the locations of exclosures 1 and 2 to open water. 
tive to effects of fish predation in the exclosures. The screening also provided additional substrate for colonization by plant-associated organisms. The two week interval between the construction of the exclosures and the start of the experiment probably allowed densities on the screening and the plants to equilibrate. Density estimates of plant-associated species were thus underestimated because the screening was not taken into account, but rates of population change during the experiment were probably affected very little.

Largemouth bass fry, between 1.5 and $2.0 \mathrm{~cm}$ in total length, were collected on 21 June with a small seine. Samples were taken of the invertebrate community associated with the Nymphaea leaves on the same day. Thirty-six samples were obtained: four taken within each of the six exclosures, and four taken directly outside each pair of exclosures at a distance of approximately $0.5 \mathrm{~m}$ from the screening. These were preserved in buffered $4 \%$ formalin. Leaf densities within the exclosures were determined by counting all Nymphaea leaves in each $4 \mathrm{~m}^{2}$ area. Numbers of leaves per $\mathrm{m}^{2}$ directly outside each pair of exclosures were not visibly different from densities inside, and were assumed to be the average of the two leaf density determinations.

Eight fry were then placed in each of exclosures 2, 4, and 6 on 22 June. Exclosures 1, 3, and 5 were retained as controls, without fish. Thirty-six samples were taken and leaf densities determined, as before, on 25 June and 29 June. Because each exclosure contained approximately 100 to 200 leaves, the 4 samples taken on each date did not greatly reduce the numbers of either leaves or invertebrates which were present. On 3 July a careful check of all exclosures revealed the presence in exclosure 5 of one largemouth bass fry, which had presumably been in the exclosure for some time, and of 4 very recently hatched sac-fry in exclosure 1 . Fry which could be seen in exclosures 2,4 , and 6 on 25 and 29 June varied from 6 to 8 individuals. Although the fish were not collected at this time, very close to the original number of 8 fish per exclosure could be assumed for the period 22 to 29 June.

\section{Population studies: 1976,1979}

In 1976, 8 samples were taken at each of 3 sites ( 1 , 7 , and 12 in Fig. 1) at approximately 1 to 2 week intervals from 20 May to 14 October. Leaf densities were estimated by placing a $1 \mathrm{~m}^{2}$ collapsible wooden frame on the water surface in 4 locations around the boat, and counting all Nymphaea leaves within the frame.

A more detailed study was conducted during June and July of 1979. A belt transect $0.35 \mathrm{~m}$ in width was constructed with nylon twine at site 1 . Five samples were taken of leaves approximately $1 \mathrm{~m}$ from a boat at each of two stations on the transect. One station was situated at $0.6 \mathrm{~m}$ depth and $4 \mathrm{~m}$ shoreward from the outer margin of the Nymphaea stand. The other was located at $0.5 \mathrm{~m}$ depth in the center of the stand, $15 \mathrm{~m}$ shoreward from the margin and $5 \mathrm{~m}$ from the shoreline. Leaf densities were determined by counting the leaves within the transect. Population estimates of plantassociated taxa were derived by combining data from the 10 samples. Counts of Sida were made every 3 days; the chironomids and chydorids were counted every 6 days. Densities of Bosmina longirostris, the most abundant free-swimming cladoceran in the lake and included here for comparison with the plant-associated groups, were also recorded in the ten samples and converted to numbers per $\mathrm{m}^{2}$ by assuming an average depth of $0.55 \mathrm{~m}$ for the 2 stations.

The lake was visited once or twice weekly during May 1979 to determine the distribution of bluegill sunfish in the littoral zone. Approximately 10 bluegills were collected on 7 occasions during May and June by seining or electroshocking and preserved in buffered $4 \%$ formalin for analysis of stomach contents. Daily checks of site 1 for schools of fry were begun on 1 June. Fry were first seen on 19 June, and 16 sites (Fig. 1) were examined daily from that date until $28 \mathrm{July,}$ when the study was terminated. Sites were less than $1 \mathrm{~m}$ in depth, with good visibility to the bottom on all but heavily overcast or windy days, and contained most of the near-shore vegetation in the lake. They were examined by rowing once around the lake and stopping at each site to scan the vegetation and surrounding water. The number of individuals in each school seen was approximated to an order of magnitude: 1-10 fish, 10-100 fish, 100-1000 fish, >1000 fish. Data were recorded for all but four days of the two month study.

Ten largemouth bass fry were collected at approximately mid-day from sites at the west end of the lake with a $1.5 \mathrm{~m}$ by $1.0 \mathrm{~m}$ seine at approximate- 


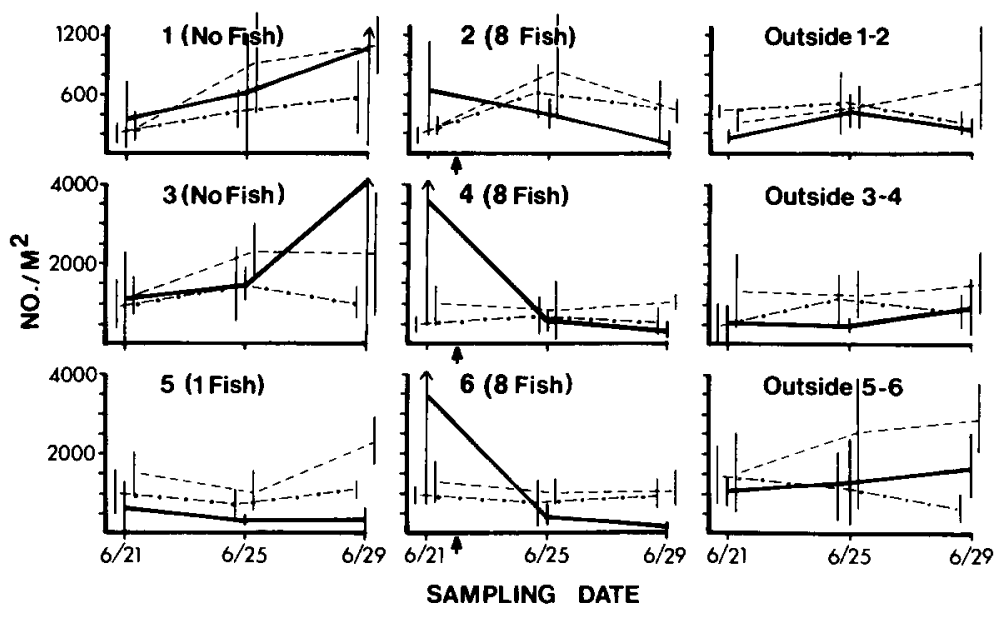

Fig. 2. Population densities of Sida (solid lines), chironomids (dashed lines) and chydorids (dash-dot lines) inside and outside the 6 exclosures, June 1978. Arrows indicate the date of introduction of largemouth bass fry into exclosures 2,4 , and 6 . Vertical lines denote 2 standard errors on each side of the mean $(n=4)$. Values for the chydorids and chironomids have been displaced slightly to the left and right, respectively, of each sampling date.

ly weekly intervals during late June and early July 1979. Fish were not collected from site 1 to avoid disturbance caused by the seining procedure. The fish were narcotized with carbonated water, then preserved in buffered $4 \%$ formalin. Only the stomachs rather than the entire digestive tracts were analyzed for prey eaten to reduce biases caused by differential digestion of the prey species (Gannon 1976).

\section{Results}

\section{Exclosures}

Locations of the six exclosures constructed at the south end of the lake in 1978 are shown in Fig. 1. Densities of Sida inside 5 of the 6 exclosures were slightly higher than in samples taken just outside the exclosures at the start of the experiment on 21 June (Fig. 2). No significant initial differences were observed for the chironomids, chydorids, or other invertebrates inside vs. outside the exclosures, or between locations (Kruskal-Wallis Test).

After fry were introduced into the even-numbered exclosures on 22 June, all three populations of Sida declined over the succeeding 7 days. Control exclosures 1 and 3 both showed population increases over this time interval. Densities of Sida outside the exclosures showed comparatively little change (Fig. 2). Exclosure 5, which contained 1 largemouth bass fry, showed consistently low population densities of Sida throughout the experiment.

Percentages of adult Sida $(>1.5 \mathrm{~mm})$ in the 3 exclosures to which fish had been added were $0.0 \%$, $1.1 \%$, and $11.4 \%$ on $29 \mathrm{June}$. In contrast, the percentages of adults in exclosures 1 and 3, without fish, were $13.4 \%$ and $21.0 \%$, respectively. Exclosure 5 had $9.6 \%$ adults. Largemouth bass fry have been shown in laboratory experiments (Fairchild 1980) to prefer larger individuals, and a temporary decline in the percentage of adults in a natural population of Sida is thus a predictable consequence of fish predation.

Control exclosures 1, 3, and 5 on 29 June had slightly more chironomids than did paired exclosures to which fry had been introduced (NS, MannWhitney Test). Densities of the chydorid Cladocera were not noticeably affected by the fry. Densities of other invertebrates were also very similar between exclosures, and inside vs. outside the exclosures (Fairchild 1980).

\section{Population data for 1976 and 1979}

A rapid decline in numbers of Sida in Cochran Lake occurred in June of both 1976 and 1979. In 1976, densities declined abruptly between 8 and 14 

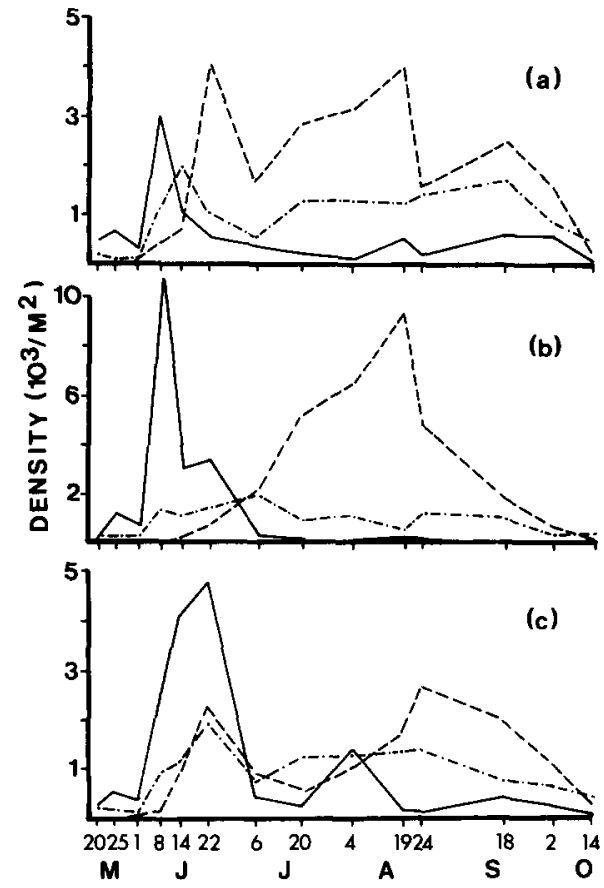

Fig. 3. (a)-(c) Population densities (1976) of Sida (solid lines), chironomids (dash-dot lines), and chydorids (dashed lines) from three sites: (a) $=$ site $1,(b)=$ site $7,(c)=$ site 12 in Fig. 1 . Values represent means of eight samples taken at each site.

June in sites 1 and 7, and between 22 June and 6 July in site 12 (Fig. 3). Sida persisted in low densities from July until the end of the study in mid-October.

The chironomids, like Sida, were abundant early in the study in 1976, then declined in late June at sites subsequently varied very little, averaging 1 to 2 sites subsequently varied very little averaging 1 to 2 thousand individuals per $\mathrm{m}^{2}$. The chydorids were the last major group to colonize the plants in 1976, but became numerically dominant during mid-and late summer in all three sites.

In 1979, a sharp drop in numbers of Sida was observed between 19 and 22 June, and was associated with high mortality of adults (Fig. 4). Densities increased once more during July 1979 before declining to about 200 individuals per $\mathrm{m}^{2}$.

Chironomid densities in 1979 reached maximal values of about 1500 individuals per $\mathrm{m}^{2}$ in mid$J$ une, then declined to less than 500 per $\mathrm{m}^{2}$ by early July (Fig. 5). The chironomids, like Sida, returned to their former densities by mid-July, but did not

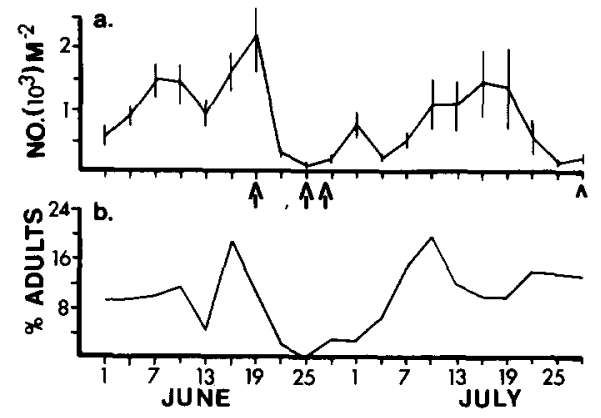

Fig. 4. (a)-(b) Population estimates for Sida during 1979. as thousands of individuals per $\mathrm{m}^{2}$. Vertical lines denote 1 standard error on either side of the mean $(n=10)$. b. the proportion of adults. Arrows indicate dates on which largemouth bass fry were seen (large arrows: $>1000$ fish; small arrow: approximately 10 fish).

decline again at the end of the study. The chydorids increased steadily to about 1300 individuals per $\mathrm{m}^{2}$ at the end of July. Whereas Sida and the chironomids were found in approximately the same densities in both years, the chydorids were less abundant in 1979. Although combined estimates for the three groups frequently reached 1 to 2 individuals per $\mathrm{cm}^{2}$ on the plants, densities expressed per $\mathrm{m}^{2}$ of lake surface were low in comparison to dominant freeswimming forms such as Bosmina (Fig. 5).

Young bluegills of the previous year were found in the littoral zone in schools of approximately 10 to 100 fish, particularly during May. Schools of larger bluegills, as well as some larger bass, were also seen occasionally from May through July. Bluegill fry were not seen during this time, however, and

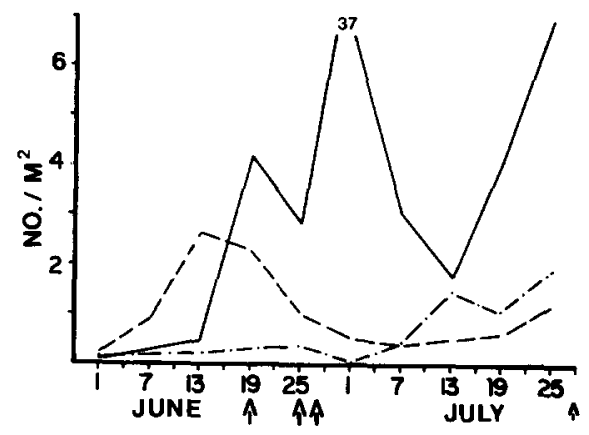

Fig. 5. Population densities (1979) of Bosmina $\left(10^{4} / \mathrm{m}^{2}\right)$ shown with solid lines, chironomids $\left(10^{3} / \mathrm{m}^{2}\right)$, with dashed lines and chydorids $\left(10^{3} / \mathrm{m}^{2}\right)$, with dash-dot lines. Data represent mean estimates of 10 samples. Arrows as in Fig. 4. 
Table 1. Gut analyses of bluegills (BG) and largemouth bass fry (LB) captured in Cochran Lake, 1979. Values represent mean numbers per fish. Ten fish were examined on all dates but $22 \mathrm{June} .1=$ Sida, $2=$ chironomids, $3=$ chydorids, $4=$ Daphnia, $5=$ Bosmina, $6=$ other plankton, $7=$ benthic invertebrates, $8=$ smaller fish.

\begin{tabular}{rlrrrrrrrrrr}
\hline Date & Species & No. & Length $(\mathrm{cm})$ & \multicolumn{1}{l}{1} & 2 & 3 & 4 & 5 & 6 & 7 \\
\hline 8 May & BG & 10 & 3.09 & 0.4 & 31.2 & 5.0 & 0.0 & 0.6 & 5.2 & 0.9 & 0.0 \\
$15 \mathrm{May}$ & BG & 10 & 3.05 & 0.1 & 2.3 & 1.6 & 0.0 & 16.5 & 1.9 & 0.7 & 0.0 \\
$22 \mathrm{May}$ & BG & 10 & 3.27 & 0.0 & 0.5 & 2.8 & 0.0 & 259.2 & 3.4 & 12.4 & 0.0 \\
$29 \mathrm{May}$ & BG & 10 & 3.54 & 0.3 & 0.2 & 1.6 & 0.0 & 5.8 & 8.6 & 4.8 & 0.0 \\
5 June & BG & 10 & 3.34 & 0.2 & 0.2 & 3.0 & 0.0 & 0.0 & 1.0 & 1.0 & 0.0 \\
14 June & BG & 10 & 3.57 & 0.0 & 6.4 & 5.4 & 0.0 & 10.9 & 2.7 & 4.7 & 0.0 \\
19 June & LB & 10 & 1.22 & 0.4 & 0.0 & 0.2 & 1.3 & 136.0 & 2.2 & 0.1 & 0.0 \\
22 June & BG & 8 & 11.08 & 0.0 & 1.8 & 0.0 & 0.0 & 0.0 & 0.1 & 3.3 & 0.0 \\
24 June & LB & 10 & 1.90 & 0.5 & 0.0 & 0.0 & 2.3 & 6.4 & 3.3 & 0.1 & 0.0 \\
2 July & LB & 10 & 2.50 & 1.5 & 0.0 & 0.1 & 27.8 & 7.7 & 7.7 & 0.1 & 0.0 \\
17 July & LB & 10 & 3.68 & 0.8 & 0.0 & 0.1 & 15.8 & 0.7 & 5.2 & 0.1 & 0.4 \\
\hline
\end{tabular}

may reside in the limnetic zone in early summer (Werner 1967, 1969). Stomach contents of the bluegills included a diversity of both free-swimming and substrate-associated invertebrates (Table 1). Densities of bluegills were very low relative to the largemouth bass fry, however. They probably exerted low but constant predation upon plant-associated invertebrates during the study.

Largemouth bass fry were sighted for the first time on 19 June 1979 at sites 1 and 4 in the lake. Schools typically contained over 1000 fish during late June, and were often seen with fish assumed to be the male parents (Kramer \& Smith 1962). Three schools were seen in the lake on 20,25 , and 27 June. More typically one or two schools were observed. On all occasions the fish were found within, or very close to, aquatic vegetation. Not all sites were utilized by the fish with equal frequency; water depth and the degree of cover provided by the vegetation probably influenced movements of the schools. Movement between sites was frequent. In only 21 of 50 cases did a site contain fry on successive days (Fairchild 1980). Fry were found continuously, however, at site 7 from 30 June to 16 July. The numbers of fish which were observed declined rapidly during July. School sizes exceeding 1000 individuals were not seen after $9 \mathrm{July}$, and no more than 100 individuals were found together after 16 July. Very few fish were seen at the end of the study. These were found singly, or in loose aggregations of 3 to 20 fish. Small school sizes, and greater densities of aquatic plants, made enumeration much less efficient at this time, and some fish were probably overlooked.
Gut analyses of the largemouth bass fry during late June and early July indicated a broad range of prey consumed (Table 1). Very young fish averaging $1.2 \mathrm{~cm}$ in length consumed large numbers of Bosmina on 19 June. Daphnia ambigua, which attained maximum densities of less than 50 individuals per $\mathrm{m}^{2}$ in early $\mathrm{July}$, was frequently eaten by the larger fry at that time. Sida and other plant-associated groups were a minor component of the diet on the four sampling dates. On 17 July fry averaging $3.7 \mathrm{~cm}$ in length had begun to feed upon smaller fish.

\section{Discussion}

The total number of largemouth bass fry observed in Cochran Lake exceeded a thousand individuals for only three weeks in late June and early July 1979. Moreover, most of the 16 locations examined in the littoral zone contained fish very infrequently. For example, large schools were observed on only three occasions at site 1 where prey populations were monitored, and fry were never seen at five of the sites. While a large school is in a given area, however, the fry appear to cause rapid declines in some prey species. The predation pressure they exert is thus extremely uneven in both space and time.

The population response of Sida to the presence of fry is much clearer than for either the chironomids or chydorids. In the exclosure experiments performed in 1978, total numbers and the percentage 
of adults both declined when fish were present. Similarly, a decline from $2.2 \times 10^{3}$ to $0.3 \times 10^{3}$ individuals per $\mathrm{m}^{2}$ in the lake between 19 and 22 June 1979 was associated with high adult mortality and coincided with the entry of fry into the study site on 19 June. The rapid and asynchronous declines of Sida in mid-June at the three sites studied in 1976 are also interpreted as the result of a small number of schools, each containing large numbers of fry, which entered the three sites at different times.

Effects of feeding by fry may be similar in other lakes. Phoenix's (1976) study of the littoral invertebrates of Lake Lacawac, Pennsylvania also indicated declines in Sida during June associated with the occurrence of fry. Brakke (1978), who constructed exclosures without fry in Lake Itasca, Minnesota, found no changes in the chydorids which could be attributed to the absence of fish. Other invertebrates were not examined, however.

The strong population decline of Sida, which may have caused its low representation in the gut contents of the fry, is understandable in view of the small numbers of Sida present in the lake. Aquatic vegetation covers approximately 5 to $10 \%$ of the total surface area and constitutes an extremely small fraction of the volume of Cochran Lake during June and July. Populations of Sida, though typically found in densities of 2 to 8 individuals per $10 \mathrm{~cm}^{2}$ on plant surfaces during the study, are correspondingly very small relative to planktonic populations. Furthermore, Sida spends much of its time in a fixed position (Fairchild 1981) and its rate of movement within lakes is low relative to most planktonic species. Consequently, whereas feeding by fry may cause locally high mortality of planktonic species such as Bosmina, their greater overall numbers and greater capacities of dispersal from areas of higher density will subsequently tend to minimize declines in prey numbers following episodes of predation in a given area. In contrast, predation upon Sida can be expected to cause population declines which are less obscured by immigration from elsewhere in the lake.

Laboratory observations of feeding by largemouth bass fry from Cochran Lake (Fairchild 1980) suggest that Sida or similar prey are a food source to which foraging behavior is specifically directed. Fry 2 to $4 \mathrm{~cm}$ in length, when placed in aquaria containing leaves of Nymphaea and abun- dant littoral prey, frequently scanned plant surfaces from distances of $10 \mathrm{~cm}$ or more. When a fish located a potential prey item on a plant, it typically approached to within $1 \mathrm{~cm}$, stopped and appeared to reinspect the item, then either picked it from the plant or retreated to scan elsewhere. Although schools of fry in Cochran Lake were found only in areas with aquatic vegetation, distribution and feeding behavior of largemouth bass fry in other lakes may differ. Elliott (1976) found that fry in Bull Shoals Lake, Arkansas fed in the limnetic zone during the day, and returned at night to nearshore areas, where they formed compact aggregations and did not feed.

Because Sida is larger than most planktonic species, is stationary and easily captured, net energy gain per individual consumed may also be greater. Large numbers of such prey may therefore increase the early growth of fry in some lakes. Largemouth bass fry are known to feed upon invertebrate prey of increasing size as they grow (Murphy 1949; Miller \& Kramer 1971). The time required before the fry become piscivorous at lengths of 4 to $10 \mathrm{~cm}$ (McCammon et al. 1964; Moyle \& Holzhauser 1978 ) is one or more months, depending in part upon the availability of invertebrate prey (Kramer \& Smith 1960; Shelton et al. 1979). Applegate \& Mullan (1967), in a comparison of largemouth bass fry in two impound ments of the White River in the Arkansas-Missouri Ozarks, concluded that the more rapid growth of fry in Beaver Reservoir was due chiefly to the greater numbers of littoral invertebrates, especially Sida and chironomids, which were present. In Cochran Lake, because Sida is so rapidly depleted by the fry, it soon becomes a small component of the diet and is probably less important to growth.

\section{Acknowledgments}

I thank J. Lehman and J. E. Gannon for their guidance of the research. The excellent work of $D$. Phoenix was also important in directing my attention toward effects of feeding by fry. Assistance in the fieldwork was provided by J. Mechling and P. Fairchild. Criticisms of early versions of the manuscript by C. Anderson, T. Getty, B. Keen, J. McDermott, and G. Smith are also gratefully acknowledged. The University of Michigan Biologi- 
cal Station generously provided techical suppori during the study.

\section{References}

Aggus, L. R. \& Elliott, G. V., 1975. Effects of cover and food on year-class strength of largemouth. In: Stroud, R. H. \& Clepper, H. (Eds.) Black Bass Biology and Management, pp. 314-322. Sport Fishing Institute, Washington, D.C.

Applegate, R. L. \& Mullan, J. W., 1967. Food of young largemouth bass, Micropterus salmoides, in a new and old reservoir. Trans. Am. Fish. Soc. 96: 74-77.

Brakke, D. F., 1978. The effect of excluding fishes on the size structure and dynamics of chydorid Cladocera, with particular reference to Camptocercus. Ph.D. thesis, Indiana Univ. $112 \mathrm{pp}$.

Elliott, G. V., 1976. Diel activity and feeding of schooled largemouth bass fry. Trans. Am. Fish. Soc. 105: 624-627.

Fairchild, G. W., 1980. Effects of littoral conditions on the distribution, behavior, and population dynamics of a filterfeeding microcrustacean: Sida crystallina. Ph.D. thesis, Univ. of Michigan. $152 \mathrm{pp}$.

Fairchild, G. W., 1981. Movement and microdistribution of Sida crystallina and other littoral microcrustacea. Ecology 62: $1341-1352$.

Gannon, J. E., 1976. The effects of differential digestion rates of zooplankton by alewife, Alosa pseudoharengus, on determinations of selective feeding. Trans. Am. Fish. Soc. 105: 89-95.

Gerking, S. D., 1962. Production and food utilization in a population of bluegill sunfish. Ecol. Monogr. 32: 31-78.

Hall, D. J., Cooper, W. E. \& Werner, E. E., 1970. An experimental approach to the production dynamics and structure of freshwater animal communities. Limnol. Oceanogr. 15: 839-928.

Hayne, E. W. \& Ball, R. C., 1956. Benthic productivity as influenced by fish predation. Limnol. Oeanogr. 1: 162-175.
Kramer, R. H. \& Smith, L. L., 1960. First year growth of the largemouth bass, Micropterus salmoides (Lacépède), and some related ecological factors. Trans. Am. Fish. Soc. 91: $29-41$.

McCammon, G. W., LaFaunce, D. \& Seeley, C. M., 1964. Observation of the food of fingerling largemouth bass from Clear Lake, Lake County, California. Calif. Fish. Game 50: 158-169.

Miller, K. D. \& Kramer, R. H., 1971. Spawning and early life history of largemouth bass (Micropterus salmoides) in Lake Powell. In: Hall, G. E. (Ed.) Reservoir Fisheries and Limnology, pp. 73-83. Am. Fish. Soc. Spec. Publ. 8

Moyle, P. B. \& Holzhauser, N. J., 1978. Effects of the introduction of Mississippi Silverside (Menidia audens) and Florida Largemouth Bass (Micropterus salmoides floridanus) on the feeding habits of young-of-the-year Largemouth Bass in Clear Lake, California. Trans. Am. Fish. Soc. 107: 574-582.

Murphy, G., 1949. The food of young largemouth bass (Micropterus salmoides) in Clear Lake, California. Calif. Fish Game 35: $159-163$.

Phoenix, D., 1976. Temporal dynamics of a natural multipredator-multiprey system. Ph.D. thesis, Univ. of Pennsylvania.

Rainwater, W. C. \& Hauser, A., 1975. Relation of physical and biological variables to black bass crops. In: Stroud, R. H. \& Clepper, H. (Eds.) Black Bass Biology and Management, pp. 306-309. Sport Fishing Institute, Washington, D.C.

Shelton, W. L., Davies, W. D., King, T. A. \& Timmons, T. J., 1979. Variation in the growth of the initial year class of largemouth bass in West Point Reservoir, Alabama and Georgia. Trans. Am. Fish. Soc. 108: 142-149.

Werner, R. G., 1967. Intralacustrine movements of bluegill fry in Crane Lake, Indiana. Trans. Am. Fish. Soc. 96: 416-420.

Werner, R. G., 1969. Ecology of limnetic bluegill (Lepomis macrochirus) fry in Crane Lake. Am. Midl. Nat. 81; 164-181.

Received 7 July 1981; in revised form 26 January 1982. 